\title{
Effect of Audit Committee Tenure on Financial Reporting Quality of Listed Deposit Money Banks in Nigeria
}

\author{
Joseph Majiyebo Onyabe \\ Joshua Okpanachi, PhD \\ Terzungwe Nyor, PhD \\ Onipe Adabenege Yahaya, PhD \\ Department of Accounting and Management, \\ Nigerian Defence Academy Nigeria \\ Mohammed Ahmed \\ Department of Accountancy, Federal Polytechnic Bida, Nigeria
}

Doi: 10.19044/esj.2018.v14n4p257 URL:http://dx.doi.org/10.19044/esj.2018.v14n4p257

\begin{abstract}
This study examines the effect of audit committee tenure on financial reporting quality of listed deposit money banks in Nigeria. The study uses panel data obtained from the Nigerian Stock Exchange factbooks and the financial statements of 14 listed deposit money banks over a period of 10 years (2007-2016). The study uses cross sectional and time series research design. Financial reporting quality was measured using the modified Jones (1991) model and changes in working capital model, while audit committee tenure was measured as the mean tenure of audit committee members. The data was analyzed using descriptive (mean, standard deviation, minimum and maximum) and inferential statistics (correlation and regression analysis). The study reveals that audit committee tenure has a negative and insignificant effect on financial reporting quality under the two models. The implication of these results is that the tenure of audit committee members is not important when considering the financial reporting quality of deposit money banks in Nigeria. The study therefore concludes that the effect of audit committee tenure on financial reporting quality of deposit money banks in Nigeria is negative and insignificant. Based on this conclusion, the study recommends that further research should be conducted on other audit committee attributes in order to see which of the attributes may have significant effect on financial reporting quality.
\end{abstract}


Keywords: Audit committee tenure, discretionary accrual, financial reporting quality, loan loss provision

\section{Introduction}

The objective of financial reporting is to provide high quality financial information about economic entities that is useful for economic decisions. According to International Accounting Standard Board (IASB, 2008), high quality financial reporting is critical to investors and other stakeholders in making investment, credit and similar decision. An important variable of financial reporting that is usually used as a yardstick of financial reporting quality is accounting earnings, (Okoh, 2012; Yahaya, Kutigi \& Ahmed, 2015) as it is reported in the published financial report of firms is expected to provide a timely and reliable input to potential investors, shareholders, creditors, employees, management, financial analysts, regulators and other stakeholders for efficient economic decisions.

The issue of financial reporting quality is of tremendous concern not only for the final users, but the entire economy as it affects economic decisions which may have significant impact. However, managerial opportunistic behaviours as well as unethical accounting practices are identified as major challenge to the quality of accounting earnings and financial reporting quality (Shen \& Hsiang-Lin, 2007). According to their study of some accounting scandals and collapse of some corporate entities (Enron, Worldcom, Xerox and Parmalat), earnings manipulation and artificial transaction are responsible for the scandal and the collapse of those entities. Moreover, most of the Chief Executive Officers (CEO) and Managers of the collapsed entities are found involved in earnings management through structuring and artificial transactions with related parties which affected earnings and financial reporting adversely (Shen \& Hsiang-lin, 2007). Earnings management as a prime factor that impairs quality of earnings is regarded as unethical and includes using managerial judgments and dearth in regulation (Bello, 2010). In a study of the effects of corporate governance mechanisms on financial reporting quality, Shehu (2012) opines that financial reporting quality could be achieved by full disclosure and higher level of transparency; and regarded corporate transparency as the widespread availability of relevant and reliable information about the periodic performance that is free from errors and misstatements. Therefore, the financial reporting quality is to promote transparency and deliver high quality Annual Report through comprehensive disclosure.

The audit committee tenure has become the focus of several debates. The resulting dilemma is that the firm is faced with the decision of whether to replace its audit committee members after a short period of time or to build and maintain a long-term tenure. The outcomes are quite conflicting. While 
some researchers have identified negative relationship between auditor committee tenure and financial reporting quality (Page \& Spira, 2005; Vafeas, 2005) others argue on positive relationship between audit committee tenure and financial reporting quality (Adeyemi, 2006; Chan, Liu \& Sun, 2012; Vafeas, 2005). In recent years, auditors have been blamed for their role in notable corporate scandals in Nigeria (Cadbury Nigeria Plc, Intercontinental Bank Plc, African Petroleum Plc, Afribank Plc). The criticism had raised lots of questions regarding whether financial reporting quality can be influenced by audit committee tenure in an organization.

Similarly, Nigerian governance regulation of the Combined Code (2008) states "length of service beyond six years for a Non-Executive Director should be subject to particularly rigorous review and should take into account the need for progressive refreshing of the Board. Non-executive directors may serve longer than nine years (e.g. three-year terms), subject to annual reelection. Serving more than nine years could be relevant to the determination of a non-executive director's independence". This is much more important and could be of greater concern for those non-executive directors who serve on the audit committee. Therefore, ongoing interest in the issue suggests a new paradigm for this study that has not been completely answered by extant research.

Several studies (Healey \& Kim, 2003; Mgbame, Eragbha \& Osazuwa, 2012; Shehu, 2011) have attempted to analyze some explanatory variables for the state of financial reporting quality. In view of these studies, audit committee tenure has become the focus of much debate. Should a firm replace its audit committee member on a regular basis, or should the audit tenure be allowed to be a long-term basis or short term basis served in audit committee? Studies on the effect of audit committee tenure on financial reporting quality are at divergent. The search for mechanisms to ensure reliable, high quality financial reporting has largely focused on the structure of audit committees' composition. The spate of audit failure in the world, especially in Nigeria, has brought great disappointment to the users of financial reports. The bane of the problem has been linked to whether a long term, short term, three or nine year tenure of audit committee members (combined code, 2008) adoption could have a significant impact is still under contention by the scholars. In Nigeria, audit setting, the challenge of audit committee tenure has not attracted much empirical studies beyond mere anecdotal opinions (Mgbame, Ezagbhe \& Osazuwa, 2012). Thus, this study examines whether audit committee tenure impact on financial reporting quality of listed DMBs in Nigeria.

In view of the research problem, the study examines the effect of audit committee tenure on financial reporting quality of DMBs in Nigeria. Therefore, the objective of the study is to find out the effect of audit committee tenure on financial reporting quality of listed deposit money banks in Nigeria 
for a period of ten years (2007-2016). Furthermore, the study test the following research hypothesis in view of research objective attributed to the study.

Audit committee tenure has no significant effect on financial reporting quality of listed deposit money banks in Nigeria.

The study is useful to a number of stakeholders in banking business environment such as managers, investors, customers and policy makers of listed deposit money banks in Nigeria. The study is also useful as part of a priori expectation that it contribute to literature, methodology, conceptualization and empirical as relates to the effect of audit committee tenure on the financial reporting quality of listed deposit money banks in Nigeria. The remaining part of the study covers the literature, methodology, results and discussions, conclusion and recommendations.

\section{Literature Review}

This section presents the conceptual framework, empirical review and theoretical literature on the effect of audit committee tenure on financial reporting quality. The earliest evidence of the use of audit committees was in the United States in the late 1930s when the New York Stock Exchange advised corporations to set up audit committees (Armitage \& Bradley, 1994). By 1978, the establishment of audit committees had become mandatory for all companies listed in the New York Stock Exchange (Williams, 1977). According to the Sarbanes-Oxley Act 2002, an audit committee refers to: A committee (or equivalent body) established by and amongst the board of directors of an issuer for the purpose of overseeing the accounting and financial reporting processes of the issuer and audits of the financial statements of the issuer; and if no such committee exists with respect to an issuer, the entire board of directors of the issuer.

Ayinde (2002) opines that the audit committee is a standing committee established to enhance corporate accountability by working with the internal auditors and management to improve and strengthen the financial reporting practices of an entity and ensure proper conduct of corporate affairs in accordance with generally accepted ethical and legal standards. Leong, Wang, Suward and Kusnadi (2015) define audit committee tenure as the tenure of audit committee directors on the board is another important factor in determining the effectiveness of audit committees in performing their monitoring role. The tenure refers to the length of time the audit committee member has served on the board. There are several views on the impact of tenure length of audit committee members on their ability to fulfill their duties competently and effectively.

The theory of inspired confidence underpins the study because it offers a linkage between the users' requirement for credible financial reports and the capacity of the audit processes to meet those needs. Developed by the Limperg 
Institute in Netherlands in 1985, the theory of inspired confidence posits that the auditor, as a confidential agent, derives his broad function from the need for expert and independent assessment plus the need for an expert and independent judgement supported by evidence. Minimizing the risk of undetected material misstatements implies that the auditor is under a duty to conduct his work in a manner that does not betray the confidence which he commands before the rational person even if the auditor may not produce what is greater than the expectation of the public. The import of the theory of inspired confidence is that the duties of the auditors derive from the confidence that are bestowed by the public on the success of the audit process and the assurance which the opinion of the accountant conveys. Since this confidence determines the existence of the process, a betrayal of the confidence logically means a termination of the process or function. Carmichael (2004) discusses the social significance of the audit and asserted that when the confidence that society has in the effectiveness of the audit process and the audit report is misplaced, the value relevance of that audit is destroyed. Audit provides assurance to the owners, management, investors and stakeholders of a company as well as provides confidence in financial reporting, corporate governance and the capital markets.

Empirically, a number of studies have examined the effect of audit committee tenure on the financial reporting quality of listed deposit money banks in Nigeria. Therefore, Dopuch, King and Schwartz (2001) examine the impact of auditor committee tenure on financial reporting quality. The result is consistent with the hypothesis that the auditor compromises his independence most often in a long term auditor contract and suggests that after all auditor tenure may have significant effect on the audit quality.

Geiger and Raghunandan (2002) posit that the effect of audit committee tenure on the credibility of financial statements can be seen from two views; regulators and economic view. In the point of regulatory view, long association between a client and an audit firm may lead to impair their independence. For example, in the United States, the Metcalf Committee report argues that long association between a corporation and an accounting firm may lead to such close identification of the accounting firm with the interests of its client's management that truly independent action by the accounting firm becomes difficult. Therefore, the report suggest a mandatory auditor rotation as a way for the accounting profession to bolster their independence from clients.

Myers, Myers and Omer (2003) find that auditor committee tenure reduces abnormal accruals whether positive or negative. Taken as a whole, these US studies run counter to the assumption that the quality of audit deteriorates as the length of auditor-client relationships increases. In France, auditors are chosen for six financial years. As a result, their mandate (and to 
some extent their tenure) enjoys a strong legal protection, initially enforced to limit opinion-shopping opportunities. However, this legal protection may have adverse effects. If this is so, the capacity of the auditor to resist managerial pressure is likely to deteriorate over time. In Nigeria, it is professionally required that audit tenure should not exceed three years but this does not appear to be enforced.

Page and Spira (2005) examine the tenure of audit committee directors on the board is another important factor in determining the effectiveness of audit committees in performing their monitoring role. The tenure refers to the length of time the audit committee member has served on the board. There are several views on the impact of tenure length of audit committee members on their ability to fulfill their duties competently and effectively. A view taken in earlier empirical studies (Page \& Spira, 2005) was that longer board service allows directors to gain more firm specific knowledge and better equip themselves to deal with complicated committee proceedings, hence resulting in improved performance in protecting shareholder's interests.

Vafeas (2005) argues that longer board service might compromise audit committee directors' independence by bringing directors and management closer resulting in directors 'befriending' management. Vafeas (2005) documents a positive association between the mean tenure of audit committee members and poor earning quality measure, showing an inverse relationship between the average tenure and earnings quality. Boone, Khurana and Raman (2008) find some evidence for a non-linear relationship between auditor committee tenure of Big 5 audits and financial reporting credibility by using the ex-ante equity risk premium. Their results show that the equity risk premium decreases in the early years of an auditor-client relationship and increases with each additional year past 13 years of auditor tenure. Ghosh and Moon (2005) analyze the perception of investors, rating agencies and financial analysts of auditor tenure by using earnings response coefficient as proxy for the perceived financial reporting credibility (perceived earnings quality). Their results show that investors and information intermediaries perceive auditor tenure as improving financial reporting credibility. In more detail, investors pay a premium of two percent for earnings as auditor committee tenure increases by an additional year. The influence of earnings for stock rankings becomes more important with extended auditor tenure (stock rankings improve by 8.2 percent by an additional year of auditor tenure) and financial analysts attach greater importance to the reported earnings in forming their expectations about future earnings with increasing auditor tenure.

Furthermore, an experimental study by Kaplan and Mauldin (2008) analyzes the impact of a five-year audit firm rotation compared to an already existing audit partner rotation on non- professional investors' perceptions of audit quality. The participants are requested to rate of how much of an income 
reducing audit difference will be recorded by the client. They find no significant difference. Under both auditor rotation conditions, investors believe that most of the audit difference will be corrected.

Dart (2009) finds differences in the level of concerns about auditor committee tenure between institutional and private investors in the U.K. Approximately 50 percent of the private investors would support the idea of a mandatory auditor rotation to strengthen auditor independence whereas the overwhelming majority of institutional investors disapprove an auditor rotation rule due to higher audit costs. Concerns about a long auditor tenure are greater if accounting skills are lower.

Oosterbosch (2009) investigates the effects of IFRS implementation on earnings management by banks though. Using a sample of listed and unlisted European banks and a single-stage regression that models the nondiscretionary part of FRQ2s and tests for income smoothing, this thesis examines first whether the level of earnings management by banks through loan loss provisioning has decreased since the adoption of IFRS. And second, whether loan loss disclosure requirements are negatively related to banks' income smoothing practices. Results show that the level of earnings management has indeed decreased since IFRS adoption, but evidence suggests that detailed disclosure requirements regarding loan loss accounting do not deter bank managers from using FRQ2 to their discretion for income smoothing (this result is not significant).

Ebimobowei and Oyadonghan (2011) posit that policy favoring mandatory rotation of auditors could have positive effects on the quality of audit reports as it would allow for fresh approach and restore public confidence in the audit function. Adeyemi and Okpala (2011) notes that an audit firm's tenure can result in a loss of auditor's independence. A long auditclient relationship could lead to an alignment of the auditors' interest and that of its client which makes truly independent behaviour of the auditor a probability.

Finally, Okolie (2014) examines the relationship and effects of auditor tenure and auditor independence on the earnings management (measured by the amount of discretionary accruals) of companies in Nigeria. The study relies on secondary data derived from various companies' financial statements and the Nigerian Stock Exchange fact book to determine and measure the level of earnings manipulations in corporate financial statements, applying an allinclusive multivariate analysis. The empirical analysis using a total of 342 company year observations, shows that Audit tenure and auditor independence exert significant effects and exhibit significant relationship with the amount of discretionary accruals of quoted companies in Nigeria. The study failed to show the effect of tenure against earnings management. 


\section{Methodology}

This study adopts correlational research design to investigate the relationships as well as the effect of the audit committee tenure on the financial reporting quality of listed deposit money banks in Nigeria. The data used in this study are acquired from the Nigeria Stock Exchange and annual of all the fourteen (14) listed deposit money banks under study for a period of ten years (2007 to 2016). In line with the research paradigm underpinning this study and consistent with the objectives of this study, Ordinary Least Square (OLS) model was employed as follows:

$$
\begin{aligned}
& F R Q 1_{i t}=\beta_{0}+\beta_{1} A C T E_{i t}+\beta_{2} L E V G_{i t}+\beta_{3} R I S K_{i t}+\beta_{4} S I Z E_{i t}+\beta_{5} P R O_{i t}+e_{i t} \\
& 1 \\
& F R Q 2_{i t}=\beta_{0}+\beta_{1} A C T E_{i t}+\beta_{2} L E V G_{i t}+\beta_{3} R I S K_{i t}+\beta_{4} S_{I Z E_{i t}}+\beta_{5} P R O_{i t}+e_{i t}
\end{aligned}
$$

Whereas:

$\beta_{0}=$ is the intercept

$\beta_{1}-\beta_{5}=$ are the parameters to be estimated in the equation

FRQ1 = Financial reporting quality, measured using the absolute value of residuals in discretionary accrual model based on modified Jones (1991) as used by Dechow \& Dichev (2002) and Yahaya, Kutigi \& Ahmed (2015).

FRQ2 = Financial reporting quality, measured using loan loss provision as used by Oosterbosch (2009) and Chang et al (2006).

$\mathrm{ACTE}=$ Audit committee tenure is measured by the mean tenure of audit committee members (Leong, et al, 2015).

LEVG $=$ Leverage is measured as the ratio of debt to equity (Yahaya, Kutigi $\&$ Ahmed, 2015).

RISK $=$ Risk is measured as non-performing loan divided total loan (Bell, Peecher \& Solomon, 2002).

SIZE = Firm size is measured by natural logarithm of total asset (Bhushan, 1999; Shehu, 2011).

$\mathrm{ROA}=$ Return on total asset is measured as earnings before interest and taxes divided by total asset (Shehu, 2011).

$\mathrm{i}=$ Firm subscript (in this case 14)

$\mathrm{t}=$ Time subscript (in this case 10 years)

$\mathrm{e}=$ Stochastic error term

\section{Results and Discussion}

This section presents the analysis of data using STATA 13 as well as the interpretation and discussion of findings. 
Table 1

Descriptive Statistics

\begin{tabular}{cccccc}
\hline Variable & Obs. & Mean & Std. Dev. & Min & Max \\
\hline FRQ1 & 140 & 0.352 & 0.332 & 0.01 & 0.91 \\
FRQ2 & 140 & -.0075 & 0.028 & -.192 & 0.136 \\
ACTE & 140 & 0.499 & 0.025 & 0.333 & 0.6 \\
LEVG & 140 & 0.175 & 0.127 & 0.01 & 0.37 \\
RISK & 140 & 0.045 & 0.065 & 0.001 & 0.458 \\
SIZE & 140 & 8.946 & 0.374 & 8.109 & 9.676 \\
PRO & 140 & 1.057 & 3.872 & -29.64 & 9.54 \\
\hline
\end{tabular}

Source: STATA 13 Outputs

As shown in the table above for all the 140 observation the average of FRQ1 is 0.352 with a minimum value of 0.01 , maximum 0.91 with a standard deviation of 0.332 . This shows that on the average, the listed deposit money banks had a positive FRQ1 the majority of the banks are in the right distribution of FRQ1. Similarly the FRQ2 with a mean value of -.0075, minimum of -.193 and maximum of 0.136 with a standard deviation of 0.028 . Also the average of ACTE is 0.499 with a minimum value of 0.333 , maximum value of 0.6 with a standard deviation of 0.025 . This shows that on the average, the listed deposit money banks had a negative ACTE the majority of the banks are not in the right distribution of ACTE.

Furthermore, LEVG average statistic value is 0.175 with a minimum value of 0.01 , maximum value of 0.37 and a standard deviation of 0.127 . This shows that though on the average, the listed deposit money banks had a positive LEVG, the majority of the banks are to the right distribution of LEVG. Also, RISK average statistics is 0.045 with a minimum value of 0.001 , maximum value of 0.458 with a standard deviation of 0.374 . This shows that on the average, the listed deposit money banks had a positive RISK the majority of the banks are in the right distribution of RISK.

Meanwhile, SIZE average statistics is 8.94 , with a minimum value of 8.946 , maximum value of 9.676 with a standard deviation of 0.065 . This shows that on the average, the listed deposit money banks had a positive SIZE the majority of the banks are in the right distribution of RISK. Finally, PRO average statistics is 1.057 , with a minimum value of -29.64 , maximum value of 9.54 with a standard deviation of 3.872. This shows that on the average, the listed deposit money banks had a positive PRO, the majority of the banks are in the right distribution of PRO. 
Table 2 Correlation Analysis

\begin{tabular}{|c|c|c|c|c|c|c|c|}
\hline VARIABLES & FRQ1 & FRQ2 & ACTE & LEVG & RISK & SIZE & PRO \\
\hline FRQ1 & 1.0000 & & & & & & \\
\hline FRQ2 & $\begin{array}{c}-0.0781 \\
0.3589\end{array}$ & 1.0000 & & & & & \\
\hline ACTE & $\begin{array}{c}-0.1841 * \\
0.0294\end{array}$ & $\begin{array}{c}-0.0856 \\
0.3146\end{array}$ & 1.0000 & & & & \\
\hline LEVG & $\begin{array}{c}0.9294^{*} \\
0.0000\end{array}$ & $\begin{array}{c}-0.0640 \\
0.4526\end{array}$ & $\begin{array}{l}0.1088 \\
0.2006\end{array}$ & 1.0000 & & & \\
\hline RISK & $\begin{array}{c}0.3523^{*} \\
0.0000\end{array}$ & $\begin{array}{c}-0.1270 \\
0.1349\end{array}$ & $\begin{array}{l}0.0146 \\
0.8636\end{array}$ & $\begin{array}{c}0.3326^{*} \\
0.0001\end{array}$ & 1.0000 & & \\
\hline SIZE & $\begin{array}{c}-0.2769 * \\
0.0009\end{array}$ & $\begin{array}{c}-0.1775^{*} \\
0.0359\end{array}$ & $\begin{array}{c}0.1683 * \\
0.0469\end{array}$ & $\begin{array}{c}0.1683^{*} \\
0.0058\end{array}$ & $\begin{array}{c}-0.3590^{*} \\
0.0000\end{array}$ & 1.0000 & \\
\hline PRO & $\begin{array}{c}-0.1770 * \\
-0.0364 \\
\end{array}$ & $\begin{array}{c}0.5299 * \\
0.0000\end{array}$ & $\begin{array}{l}0.0189 \\
0.8249 \\
\end{array}$ & $\begin{array}{c}0.1762 * \\
0.0373 \\
\end{array}$ & $\begin{array}{c}-0.2659^{*} \\
0.0015 \\
\end{array}$ & $\begin{array}{c}0.2028 * \\
0.0162\end{array}$ & 1.0000 \\
\hline
\end{tabular}

Source: STATA 13 Outputs

As shown in table 2 the correlation coefficients were calculated to ascertain the pairwise association between the dependent variables and explanatory and identify both the direction and quantum of the relationship. It should be noted that correlation greater than 0.80 indicate multicollinearity problem. In table 2, result shows a correlation coefficient of 0.0855 between FRQ1 and ACTE; $-0.1841 *$ between FRQ2 and ACTE; -0.0856 between LEVG and FRQ1; -0.0640 between LEVG and FRQ2; 0.1088 between LEVG and ACTE. In the three cases the result suggest good relation except LEVG and FRQ2 that is negative. Also RISK and FRQ1 shows 0.3523*; RISK and FRQ2 shows -0.127; RISK and ACTE shows 0.0146; RISK and LEVG shows $0.3326^{*}$. In the four cases the result suggest good relationship except RISK and ACTE with negative relationship. Similarly, SIZE and FRQ1 shows 0.2769*; SIZE and FRQ2 shows -0.1775*; SIZE and ACTE shows 0.1683*; SIZE and LEVG shows 0.1683*; SIZE and RISK shows -0.3590*; SIZE and SIZE shows $0.2028^{*}$. In the five cases the result suggest good correlation. Also PRO and FRQ1 shows -0.1770*; PRO and FRQ2 shows 0.5299*; PRO and ACTE shows 0.0189; PRO and LEVG shows 0.1762*; PRO and RISK shows $-0.2659^{*}$; PRO and SIZE shows $0.2028^{*}$. In the six cases the result suggests good correlation. Table 2 also shows that there is no presence of multicollinearity among the independent variables since none of the correlation coefficients is equal to 0.80 .

\section{Table 3}

Shapiro-Wilk W Test for Normal Data

\begin{tabular}{cccccc}
\hline Variables & OBS & $\mathrm{W}$ & $\mathrm{V}$ & $\mathrm{Z}$ & Pro>Z \\
\hline FRQ1 & 140 & 0.86294 & 15.034 & 6.122 & 0.00000 \\
FRQ2 & 140 & 0.72011 & 30.700 & 7.735 & 0.00000 \\
ACTE & 140 & 0.94340 & 6.208 & 4.124 & 0.00002 \\
LEVG & 140 & 0.92311 & 8.434 & 4.816 & 0.00000 \\
RISK & 140 & 0.61372 & 42.370 & 8.463 & 0.00000 \\
SIZE & 140 & 0.98287 & 1.879 & 1.425 & 0.07709 \\
PRO & 140 & 0.55994 & 48.269 & 8.757 & 0.00000 \\
\hline
\end{tabular}

Source: STATA 13 Outputs 
Table 3 shows the result of normality test using Shapiro-Wilk W test. As shown in table 3, the Shapiro Wilk test for all the variables show p-values less than 0.05 . This indicate that at $5 \%$ level of significant, the residuals are not normally distributed.

Table 4

Heteroscedasticity Test

\begin{tabular}{ccc}
\hline Models & $\mathrm{Chi}^{2}(1)$ & Prob $>\mathrm{Chi}^{2}$ \\
\hline FRQ1 & 18.06 & 0.0000 \\
FRQ2 & 34.39 & 0.0000 \\
\hline
\end{tabular}

Source: STATA 13 Outputs

As shown in table 4, the p-value for model FRQ1 and FRQ2 are significant meaning they are less than 0.05 which suggests that there is heteroscedasticity problem in their data set. Therefore the solution to the normality and heteroscedasticity problem is to use robust standard error in their regression analysis.

Table 5

Regression Result for the models

\begin{tabular}{ccccccc}
\hline Model & \multicolumn{3}{c}{ FRQ1 } & \multicolumn{3}{c}{ FRQ2 } \\
\hline Variable & Coeff. & \multicolumn{1}{c}{$\mathrm{T}$} & $\mathrm{P}>\mathrm{t}$ & Coeff. & $\mathrm{t}$ & $\mathrm{P}>\mathrm{t}$ \\
\hline ACTE & -.6147127 & -1.52 & 0.130 & -.0455446 & -0.59 & 0.555 \\
LEVG & 2.265968 & 23.76 & 0.000 & .0334133 & 1.69 & 0.093 \\
RISK & .1939147 & 1.10 & 0.314 & -.0569332 & -1.69 & 0.094 \\
SIZE & -.0375272 & -1.01 & 0.271 & -.0238222 & -2.78 & 0.006 \\
PRO & .0000811 & 0.03 & 0.975 & .0046041 & 9.24 & 0.000 \\
Cons & .5894463 & 1.63 & 0.103 & .2201757 & 2.77 & 0.007 \\
F(5, 121) & $=635.49$ & & & $=20.10$ & & \\
Prob >F & $=0.0000$ & & & $=0.0000$ & & \\
$\mathrm{R}^{2}$ & $=0.9515$ & & & $=0.4537$ & & \\
Adjusted R $\mathrm{R}^{2}$ & $=0.8716$ & & & $=0.3536$ & & \\
\hline
\end{tabular}

Source: STATA 13 Outputs

Table 4 shows the regression results for the two models, the prob $>\mathrm{F}$ in the two cases is 0.0000 , which suggest strong overall fitness of the two models. Also, $\mathrm{R}^{2}$ which shows the amount of variance in the dependent variables explained by the explanatory variables in the two cases are FRQ1 (95\%) and FRQ2 (45\%). However, the adjusted R-square which is a better predictor of variations in the dependent variables since it takes care of the errors in the model shows FRQ1 (87\%) and FRQ2 (35\%).

Also table 5 shows that ACTE is negative and insignificant on FRQ1 $(\beta=-.6147127, \mathrm{t}$-value $=-1.52, \mathrm{p}$-value $=0.130 ;$ negative and insignificant effect on FRQ2 $(\beta=-.0455446$, $\mathrm{t}$-value $=-0.59$, $\mathrm{p}$-value 0.555). Similarly, table 4 shows that LEVG has a positive and significant on FRQ1 ( $\beta=$ 2.265968 , t-value $=23.76$, $\mathrm{p}$-value 0.000 ; but positive and insignificant effect on FRQ2 $(\beta=.0334133, \mathrm{t}$-value $=1.69, \mathrm{p}$-value $=0.093$. Positive and 
insignificant effect of RISK on FRQ1 $(\beta=1738616$, $\mathrm{t}$-value $=1.10$, $\mathrm{p}$ value $=0.314)$. Negative and insignificant effect on FRQ2 $(\beta=-.0569332, \mathrm{t}-$ value $=-1.69, \mathrm{p}$-value $=0.094)$.

Furthermore, negative and insignificant of SIZE on FRQ1 $(\beta=-$ .0375272 , t-value $=-1.01, \mathrm{p}$-value $=0.271)$, and negative and significant effect on FRQ2 ( $\beta=-.0238222$, $\mathrm{t}$-value $=-2.78, \mathrm{p}$-value $=0.006)$. Positive and insignificant of PRO on FRQ1 $(\beta=.0000811$, t-value $=0.03$, $\mathrm{p}$-value $=0.975)$; positive and significant on FRQ2 $(\beta=.0046041$, t-value $=9.24$, $\mathrm{p}$-value $=$ 0.000 ). Also, the $t$-value test the hypothesis that the coefficient is different from 0 . To reject this, there is need for a $t-v a l u e$ of \pm 0.95 at 0.05 confidence interval. In addition the two tail p-value tests the hypothesis that each coefficient is different from 0 . To reject this the $\mathrm{p}$-value has to be $\leq 0.05$. In view of the above results and the discussions that follows:

The null hypothesis which states that audit committee tenure has no significant effect on financial reporting quality of listed deposit money banks in Nigeria (ACTE) is hereby accepted under FRQ1 and FRQ2 respectively. The constant (alpha) in the model means that if the independent variables (ACTE, LEVG, RISK, SIZE and PRO assume 0, on the average FRQ1 score will be .5894463; and FRQ2 score would be .2201757. the constant is simply where the regression line cross the axis the dependent variable axis the minimum score of audit committee tenure effectiveness. The result is inconsistent with Leong, Wang, Suwardy and Kusnadi (2015) and Ndubuisi and Ezechukwu (2017). The implication of these results is that the tenure of members of the audit committee is not important when considering the financial reporting quality of listed deposit money banks in Nigeria. It therefore suggests that individual banks may decide the tenure of their audit committee members.

\section{Conclusion and Recommendation}

The study investigates the effect of audit committee tenure on financial reporting quality of listed deposit money banks in Nigeria. The study concludes that audit committee tenure has an insignificant effect on financial reporting quality of listed DMBs. Also, leverage shows positive and significant effect on financial reporting quality. However, risk shows mixed results (positive and insignificant on FRQ1 and negative and significant on FRQ2). Firm size shows negative effect on financial reporting quality. PRO shows positive effect on financial reporting quality under the two models. Based on the conclusion, the study recommends that furthermore research should be done to examine other audit committee attributes that may influence financial reporting quality of listed DMBs in Nigeria. 


\section{References:}

1. Adeyemi, S. B. (2006). Impact of accounting standards on financial reporting in Nigeria. Unpublished $\mathrm{PhD}$ Thesis, University of Lagos.

2. Armitage, J .L., \& Bradley, R. J. (1994). Audit committees. The Nigerian Accountant, 8(1), 18-29.

3. Ayinde, I. (2002). Audit committee: History and evolution. Presented at a National Seminar on Enhancing audit committee effectiveness, organized by ICAN, Lagos.

4. Auditing Profession Act (2002). Number 26 of 2002. Pretoria: Government Printer. APA,

5. Barbadillo, E., \& Aguilar, N. (2008). Does auditor tenure improve audit quality? "Mandatory auditor rotation versus long term auditing: An empirical analysis". Working paper, University of Cadiz, Spain.

6. Bell, T., Peecher, M., \& Solomon, I. (2002). The strategic-systems approach to auditing in T. Bell and I. Solomon (Ed.), Cases in Strategic-Systems Auditing, KPMG. 1-34.

7. Blanchet, B. (2000). Corporate governance, audit committee on firm performance. Journal of Corporate Finance, 14(3), 257-273.

8. Boone, J. P., Khurana I. K., \& Raman K. K. (2008). Audit firm tenure and the equity risk premium. Journal of Accounting, Auditing and Finance, 23, 125-140.

9. Carmichael, D. R. (2004). The PCAOB and the social responsibility of auditors, Accounting Horizons, 18(2), 127-133.

10. Central Bank of Nigeria (2010). Deposit Money Banks Activities Report. Available from: http://www.google.com/published7/12/2012. CBN.

11. Chan, A. M. Y., Liu, G., \& Sun, J. (2012). Independent audit committee members' board tenure and audit fees. Accounting and Finance. 10(1), 46- 62.

12. Dart, E. (2009). UK investors' perceptions of auditor independence. Working Paper, Cardiff University.

13. Dechow, P., \& Dichev, I. (2002). The quality of accruals and earnings: The role of accrual estimation errors. The Accounting Review, 77, 3559.

14. Dopuch, N. D., King, R. R., \& Schwartz, R. (2001). An experimental investigation of reputation and rotation requirements. Journal of Accounting Research, 39(1), 93-117.

15. Geiger, M., \& Raghunandan, K. (2002). Auditor tenure and audit quality. Auditing: A Journal of Practice and Theory, 21(1), 187-196.

16. Hausman, J. A. (1978). Specification tests in econometrics, Econometric, 46(6), 1251-71. 
17. Healy, P. M., \& Kim, M. (2003). A review of the earnings management literature and its implication for standard setting. Accounting Horizons, $13,365-383$.

18. IASB, (2010). Conceptual Framework for Financial Reporting. London.

19. IASB, (2008). Exposure draft on an improved conceptual framework for financial reporting: The objective of financial reporting and qualitative characteristics of decision-useful financial reporting information, London.

20. Jones, J. (1991). Earnings management during import relief investigations, Journal of Accounting Research, 29(2), 193 - 228.

21. Knapp, M. C. (1991). Factors that audit committee members use as surrogates for audit quality. Auditing: A Journal of Practice \& Theory, $10,35-52$.

22. Joshi, D., \& Ramadhan, O. (2002). Quality determinants of independent audits of bank. Journal of Corporate Finance, 18(2), 8796.

23. Lai, K. W., \& Krishnan, G. V. (2009). Are non-audit services associated with firm value? Evidence from financial information system-related services. Journal of Accounting and Finance, 49, 599617.

24. Limperg Institute, (1985). The social responsibility of auditors: a basic theory on auditors function. The Limperg Institute, Netherlands.

25. Lindberg, D. L. (2001). Discussion of the demand for auditor reputation across international markets for audit services. The International Journal of Accounting, 36(4), 429-432.

26. Leong, K. S., Wang, J., Suwardy T., \& Kusnadi, Y. (2015). Audit committees and financial reporting quality in Singapore. Institutional knowledge of Singapore Management University. Research of Collection School of Accountancy.

27. Mgbame, C. O., Eragbhe, E., \& Osazuwa, N. P. (2012). Audit partner tenure and audit quality: An empirical analysis. European Journal of Business and Management, 4(7), 154-162.

28. Myers, J. N., Myers, L. A., \& Omer, C. T. (2003). Exploring the term of the auditor-client relationship and the quality of Earnings: A case for mandatory auditor rotation? The Accounting Review, 78(3), 779 799.

29. Naser, K., \& Naebah, K. (2003). Determinants of the depth of voluntary disclosure in the board of directors statement in a sample of Jordanian listed companies, Advances. Int. Accounting, 6(2), 71-82. 
30. Ndubuisi, A. N., \& Ezechukwu, B. O. (2017). Determinants of audit quality: Evidence from deposit money banks listed on Nigerian Stock Exchange. Journal of Finance, 6(2), 17-28.

31. Ofoegbu, G., \& Okoye, E. (2006). The relevance of accounting and auditing standards in corporate financial reporting in Nigeria: Emphasis on compliance. The Nigerian Accountant, 39(4), 45-53.

32. Okolie, A. O. (2014). Auditor tenure, auditor independence and accrual-based earnings management of quoted companies in Nigeria. European Journal of Accounting Auditing and Finance Research, 2(2), 63-90.

33. Oosterbosch, V. R. (2009). Earnings management in the banking industry: The consequences of IFRS implementation on discretionary use of loan loss provisions. Master Thesis Submitted to School of Economics, Erasmus University Rotterdam for the award of Master Accounting, Auditing \& Control, FEM 11032.

34. Page, M., \& Spira, L. (2005). Ethics, independence and the conservation of ambiguity. Business Ethics: A European Review, 140, 301-316.

35. Shehu, U. H. (2011). Corporate governance and financial reporting quality: A study of Nigerian deposit money banks. International Journal of Research in Computer Application and Management, 1(6), 12-19.

36. Shen, C., \& Hasiang-Lin, M. (2003). Earnings management using the valuation allowance for deferred tax assets under SFAS No. 109. Contemporary Accounting Research. 20, 579- 611.

37. Vafeas, N. (2005). Audit committees, boards, and the quality of reported earnings. Contemporary Accounting Research, 22, 10931122.

38. Watts, R., Zimmermann, L., \& Jerold, L. (1986). Positive Accounting Theory. New Jersey: Englewood Cliffs.

39. William, S. M. (1977). The future of accounting, reliability and auditor independence.

40. Accounting Horizons, 10, 76 - 97.

41. Yahaya, O.A., Kutigi, U.M., \& Ahmed, M. (2015). International financial reporting

42. standards and earnings management behaviour of listed deposit money banks in Nigeria. European Journal of Business Management, 7(18), $70-82$. 